\title{
Article \\ The Role of Persian Reading Text Books of the First to the Third Primary School in Presenting Religious Doctrines in Iran
}

Maryam Jalali

Department of Persian Language and Literature, Shahid Beheshti University, Tehran, Iran; ma_jalali@sbu.ac.ir

\begin{abstract}
Transmission of values and religious concepts to children is one of the most important issues in the third millennium and it has drawn varied and different views among experts and scholars in the world. Research specialized in religious literature for children and adolescents create new capacities in the presentation of religious concepts to the group. Plans have been considered to transfer values and religious concepts in the curricula of primary school children in the group in Iran. It is one of the topics that the authors note to the introduction of the minutiae of religion in the first three elementary grades. In this study, the collection and analysis methods providing content related to the minutiae of religion in reading books the first till third sections of the years 20132015. In addition, the plan includes aspects of other branches of religion in these books on information collected from text books that collected and classified. The result is that "definitely good and forbidding the evil" and "prayer" have the highest frequency of applications in the selected books. Further branches made of branches of religion in these books, represents the values of religious, moral and social as well.
\end{abstract}

Keywords: religious, children, Reading books, school, Iran

\section{Introduction}

Many theological researchers have considered making a relationship between religion and children fantasy world and they have challenged the concepts of modern societies in this regard.

The policies governing each society are founded on the dominant ideology of that certain society, so it is essential to nurture the conceptual bases. Children and adolescents are considered as the main foundations of every society. In religious societies, religious values are reflected on the personal and social life of the children and adolescents. In this regard, a research was conducted in Europe and it was demonstrated that children trained religiously have become more successful one than the ones who weren't.

And they have been better people in their adult lives [1] [P 365].Religious values are reflected more in Islamic societies than others. Adolescents are like the potential factors guarantee the future stability of their religious society, that is why, Mohammad the prophet, says that the religion of Islam emphasizes on the treatment of children as the ones preserving the future values of their society.

Studies demonstrate that children spend almost $75 \%$ of their time on visual or reading texts [2] [P67].In case, this situation is properly used, it is directed into a healthy religious society. Children are recognized as the future owners of any society. This ideology aims at maintaining the eternal perfection of human and its effects guarantee the stability of society. In fact, religious consequences determine the religious absorption of in societies. Hence, religious text books specify the degree of 
religion attraction. As a result, it is essential to consider religious text books in the schools 'curriculums [3] [P49].

The religious literature of children and adolescents follows the same principles of the beginning of Islam called Islamic training of children. It aims at inducing religious thinking in the minds of children and adolescent.Ghezel Ayagh divides the genre of these texts into old literature, contemporary literature and documentary literature [4] [P56]. So, religious literature is a subbranch of the documentary literature of children and adolescents. It holds Islamic theories and principles, religious rites and stories, history and biographies and tries to prepare conditions to religiously nurture children. The training and education ministry of Iran has been always remarking these issues in the educational curriculums and many authors have written about religious concepts in their books.

Religious doctrines are like a tree rooted in practical religious subjects and this tree is very fruitful [5] [p11].The importance of transmitting religious concepts to children are not less than other doctrines because they grow the branches of the religion. The religious subjects are considered from direct curricular and hidden ones points of view is essential to scrutinize how the religious issues both directly or indirectly even as pre-determined ones are presented in the curriculums [6] [p69] Text books play an important role because they are considered as factors affecting the development of religious values among students. Since the content of text books is trying to imply alternatives for a suitable religious conditions, many religious researchers have concentrated on this issue [7] [p95]. It is not good to only reflect religious subjects in theology text books. Reading books should be taught in order to improve children's reading ability and these text books directly and indirectly transmit extreme religious concepts. The present research aims at describing religious concepts in the reading books of the first to the third grade of primary schools. The first series published in 2012-2013.

The necessity: the current research follows an applied method to improve curriculums and produce religious literature.

Main Question: what religious functions have been presented in the reading books of the first three grades of the primary schools?

Sub-question: what are the religious supplementary assignments in reading books and how are they classified?

The sub branches of religion include praying, fasting, paying on fifth of your wealth, Zakat, Jihad, Haj, Guiding and abandoning, "Tavalla" and "Tabara” which will be provided and analyzed.

\section{The methods of presenting religious issues in reading books}

The types of literature presented due to the children's needs are responsible to expand religious concepts in primary schools. Besides, it is significant to consider innovation for this age group. Within the last few years, UNESCO has been emphasizing on innovation in curriculums [8] [P263]. Innovation in religious subjects makes students to be fond of religious training [9] [p40] .This project will be successful when children don't feel tired of the repeated subjects. Hence, innovation is the best alternative. Children grow both mentally and physically in their adolescence and childhood.

It is obvious that each age requires its needs and identifying them contribute the children writers' to create more comprehensible works for their addressee [10] [P 35]. As there are addressees for the religious issues, religious training are done for them. Literature is raised from art and the religious issues are considered as recognizing principles. In fact, the addressee should communicate with them, otherwise the attempts of authors will be fruitless. Correct choice of concepts and applying new methods make children closer to religious training. This subject is important enough that some 
groups consider fundamental differences between the adults' religious literature and children's religious literature. Authors have used two direct and indirect methods to assess religious issues and represent them to the addresses in reading books:

\section{- Direct training methods}

Some groups believe that the training, moral and religious aspects are the prior subjects in the literature of children and adolescents [11] [P 685]. Besides training issues, some people have added literary and artistic values to it [12] [P 27].

It is not easy to evaluate the religious concepts regarding the needs, thoughts and the level of literature matching with the addressee. Thus, it doesn't disturb the children's comprehension. The fact is that obligatory methods are applied to practice the religious literature of children in the text books. However, this obligation doesn't always mean the direct religious message and doctrines. Undeniably, a great amount of religious concepts are pedagogical and training and the literature of children and adolescents convey religious concepts and affect text books. Meantime, the dominant of pedagogical dimension of the religious issues might fade the role of literature and the writer has to directly define their outlooks. The purpose of this method is only the educational one and religious issues directly use the dos and don'ts in an advising manner in sentences for the students. This type of training is very popular in the world. Some experts agree to teach religious concepts to children especially at religious centers [13,14] [P 152] [14] [P11] . Cliché preaching statements are applied to convey precious and religious concepts in this method.

\section{- Indirect Training Methods}

This type of training is very popular all around the world. The stories of prophets and religious doctrines of great religious men have been taught to children in form of literary and artistic methods and a fantastic and amusing ambiance have attracted children to learn these subjects. In this method, literature has contributed the intended thoughts of the writer to be shaped in an artistic and delicate pattern. This method has been practiced in West and it has been able to successfully nurture the religious needs of children [15] [P 333]. It is recommended to use indirect training methods to convey heavy religious subjects to children.so, religious issues aren't ignored and they influence the treatment of their addressee. The practical examples of human behaviors have been in form of story, poem, humor, entertainment and games which are used in the reading text books. Kant believes the religious training of children should be founded on conscious, behavior and indirect transmission. Since the post moderns deny the expansion of religious thoughts in the text books, it is essential to take policies preventing these outcomes [16] [P 51] .Improving religious values and training the religious trainings in text books are identified as the most important factors affecting the strength and expansion of religious values for a religious based society. Consequently, the religious values are perfectly and completely accepted by the addresses [17] [P 40]. However, best alternatives should be taken to induce religious subject to children based on their age needs. The following table illustrates the application of religious values in reading books.

\section{Conclusions}

Guiding and abandoning, Praying, Jihad, Tavalla and Haj are the most prominent religious issues presented by direct and indirect method in the reading books of the first three grades of the primary schools. Taking social responsibilities, religious communications are identified as other religious assignments induced by indirect method. Comparing these methods indicate that the partial religious assignments combined with indirect methods are conveyed by indirect method to 
the addressee in the reading books. Furthermore, there are some failures in defining religious issues in reading text books. As literature is dominant in reading text books, authors can optimally use the indirect method to convey religious sub-branches. Stories, poems, amusements along with transmitting religious issues direct students to socially communicate with. Holistically, religion will affect the religious training and it will have precious issues.

\section{References}

1. Regnerus, M. D. "Shaping Schooling Success: Religious Socialization and Educational Outcomes in Metropolitan Public Schools." Journal for the Scientific Study of Religion 39.(2000): 363-370.

2. Brawise, $\mathrm{p}$ and Ehrenberg, A. Media Matter: TV Use in Childhood and Adolescence, Norwood. NJ: Aablex,1988, P67.

3. Khawaldeh, M; Shouha, A. "Values in educational books deserted the ranks of the four upper stage cores in Jordan". Bulletin of the Association of Arab Universities of Education and Psychology 3. (2005): 43-55.

4. Ghezel Ayagh, S. The children's literature and promote reading (Persian book), Tehran: Samt Press, 2006, P56.

5. MakaremShirazi, N. Clarify der debt issues. Qom Press, 2009,p11.

6. Nurian, $\mathrm{M}$. “Introducing the prayer, fasting, Jihad, Hajj, Khums and Zakat in social science books and reading in primary schools in Iran". Journal of Islamic education11(Persian journal), (2011): 59-79.

7. Hakimzadeh, R, Mousavi, S. A"Teaching religious values in the content of school textbooks: check the status of existing and proposed strategies for optimal situation." Journal of Curriculum Studies11" (Persian Journal), (2008): 95-117.

8. Gholizadeh, A. Sociology of education. Kashan: Mohtasham Press, 1998, P 263.

9. Taghavinasab et al. "The Innovation Imperative in religious education from the perspective of scientific foundations, religious and philosophical." Journal of Islamic education9. (2009).P: 25-46.

10. Jalal, M. Adaptation in children's literature. Second edition Tehran: Iranian Women's Association Publisher, 2016. p35.

11. Lamp, p. Sanity, M. Children's literature, The International encyclopedia of education, Pergamum press, 1975, P 685.

12. Collie, J. and Slater, S. Literature in the language classroom, England, Cambridge University press. 1987, P 27.

13. McCleary, R.M., Barro, R.J. Religion and political economy in an international panel. Journal for the Scientific Study of Religion 45. (2006):149-175.

14. Wilson, J. Religion in American Society: The Effective Presence, Prentice-Hall, Englewood Cliffs,1978, p11.

15. Nock, S.L. Sociology of the Family. Prentice Hall, Englewood Cliffs, 1992,P 333.

16. Sajadi, SM. Moral Education from the perspective of Postmodernism and Islam. Qom, the center of Islamic education, 2000, p 51.

17. Hood, R W., Peter C. Hill, and W. Paul Williamson, The Psychology of Religious Fundamentalism. New York: Guilford Press, 2005, p 40.

(C) 2016 by the author; licensee Preprints, Basel, Switzerland. This article is an open access article distributed under the terms and conditions of the Creative Commons by Attribution (CC-BY) license (http://creativecommons.org/licenses/by/4.0/). 